\title{
Keuangan Syariah Dalam Literasi Modern
}

\author{
${ }^{1}$ Pandu Dewanata, ${ }^{2}$ Kasful Anwar US \\ 1-2 Prodi Ekonomi Syariah, Fakultas Ekonomi dan Bisnis Islam, Universitas Islam Negeri Sultan \\ Thaha Saifuddin Jambi, Jambi, Indonesia
}

Article history

Received. : 1 November 2021

Revised : 10 November 2021

Accepted. : 20 November 202

*Corresponding Author:

Pandu Dewanata

Universitas Islam Negeri

Sultan Thaha Saifudin

Jambi

Email:

dewanata964@gmail.com
Abstrak: This article contains an explanation of the management of Islamic finance in modern literacy in Indonesia, nowadays it is understood that Indonesia still has a literacy level which is considered quite low, so it needs to be reviewed. This journal only describes descriptively about the material and theories regarding financial literacy and financial management in a person which is an important science to be able to improve his financial well-being.

Keywords: Financial Literacy, Management, Welfare.

\section{PENDAHULUAN}

Sebagai negara dengan jumlah penduduk muslim terbesar di dunia, tidak mengherankan jika di Indonesia penerapan Syariah Islam diakui hukumnya. Bila membahasnya secara universal, Syariah Islam bisa diartikan sebagai hukum yang ada dan mengatur seluruh tatanan kehidupan umat Islam dengan dasar hukum yang mengacu pada Al-Qur'an dan Hadist yang sahih (benar dan baik). Perkembangan yang pesat membuat seluruh aspek juga ikut berkembang termasuk juga bidang aspek ekonomi.

Bidang ekonomi sering menjadi acuan perkembangan dalam literasi modern, semua hal mengacu pada tuntutan angka dan angka. Dan hal itu juga tidak lepas dari pandangan Syariah Islam yang sering di kenal sebagai Ekonomi Islam.

Ekonomi Idlam berembang dan terus menguatkan keterlibatanya dalam perkenomian termasuk dalam membentuk Lembaga keuangan berbasais Syariah, yakni bank Syariah. Pertumbuhan beberapa asset yang kian meningkat membuat trand Bank Syariah terus mendapatkan nama. Namun, dengan begitu tidak mejamin bahwa nasabah dalam Bank berbasis Syariah ini memahami dan benar benar mengerti mengenai manjaemen keuangan dalam Syariah Islam.

Pengetahuan seseprang mengenai manajemen keuangan disebut sebagai literasi menjemen keuangan yang termasuk pula di dalamnya bagaimana seseorang mampu mengelola serta mengolah keuangannya yang bertujuan untuk mencapai satu hal yang dinamakan kesejahteraan. Literasi keuangan menjadi sebuah kebutuhan dasar bagi setiap 
insan mausia agar hidupnya bia terhindar dari masalah financial resesi. Masalah keuangan yang muncul bukan sebatas pendapatan dan pengeluaran saja, namun juga membahas pemisahannya.

Tidak sedikit studi yang memabahas tentang ekonomi, terkhususnya ekonomi Syariah, manajemen perbankan Syariah, produk produk Lembaga keuangan yang berbasis Syariah. Namun, menjadi sbeuah pertanyaan bagi peneliti, bagaimana bisa masyarakat dapat memehami dan menggunakan semuanya bila literasi keuangan syariahnya masih tergolong rendah.

Dalam survey yang di lakukan oleh Otoritas Jasa Keuangan, medapati hasil bahwasannya literasi keuangan tingkat umum saja di Indonesia masih terhitung rendah, belum di khsususkan dengan literasi keuangan Syariah maupun literasi manajemen. Namun justru inilah yang menarik untuk di bahas, yakni literasi manjaemen dan literasi keuangan Syariah dalam era modern seperti ini.

Kunt, Klapper Dan Randall pada 201 memberikan oadangannya dan mengkasifikasikan Muslim menjadi tugas kategori yang memliki hungan dengan prefensi terhadap keuangan konvensional maupun islam. Yakni : Pertama, Muslim yang menolak untuk menggunakan prosuk keruangan konvensional karena menganggap melanggar syariat Islam. Keuda, Muslim yang menggunaan atau akan menggunakan kredit Islam. Ketiga, Muslim yang menggunakan atau akan menggunakan kredit konvensional dan akan terus menggunakannya sekalipun harganya kompetitit fengan produk yang berlabel Syariah.

Sampai saat ini, saya belum menemukan sebuah penelitian di Indonesia mengenai hal yang mengukur tingkat literasi keuangan masyarakat khsusunya literasi manajemen keuangan Syariah, sehingga saya memutuskan untuk membahas tema ini dalam jurnal kali ini

\section{METODE PENELITIAN}

Adapun metode yang digunakan dalam penelitian ini adalan deskriptif kualitatif, yaitu mengungkakan kejadian dan fakta berdasarkan keadaan, fenomena, vaiabel dan keadaan yang terjadi pada saat penelititan berlangsung dengan memberikan suguhan apa yang sebenarnya terjadi, penelitian ini menafsirkan dan menguraikan data yang bersagkutan dengan situasi yang terkadi, sikap serta pendangan yang terjadi di dalam sebuah lingkaran daerah samel, temtangan antara dia variabel atau ebih, hubungan antar variabel yang timbul serta perbadaan anatra fakta dan opini, juga pengaruh terhadap satu kondisi dengan kondisi yang lain.

\section{HASIL DAN PEMBAHASAN}

\section{A. Definisi dan Konsep Literasi Keuangan}

Menurut Kamus Besar Bahasa Indonesia, Literasi merupakan kemampuan menulis danmembaca, pengatahuan atau keterampilan dalam bidang atau aktivitas tertentu dengan kemapuan individu mengolah informasi dan pengetahauan untuk kecakapan hidup. Literasi berlaku pada semua bidang yang salah satunya juga bisa di gunakan dalam literasi keuangan.

Menurut Otoritas Jasa Keuangan, Literasi Keuangan merupakan pengetahuan, keterampialan dan keyakinan dalam mengelola keuangan untuk mencpaai kesejahteraan masyarakat. sehingga dari definisi itu dapat dibrikan klasidikasi literasi keuangan berdasrakan indicator pengetahuan, keterampilan dan sudah sampai emnyakini akan oengelolaan keuangan itu. Adapun tujuan ;iterasi keuangan menurut Pengawas Otoritas Jasa Keuangan yakni :

1. Meningkatkan kualitas pengambilan keputusan keuangan individu, dan 
2. Perubahan sikap serta perilaku individu dalam pengelolaan keuangan menjadi lebih baik, sheingga mampu menentukan dan memanfaatkan Lembaga, produk dan layanan jada keuangan yang sesuai dengan kebutuhan dan kemampuan konsumen dan atau masyrakat dana tangka mencapai kesejahteraan.

Literasi keuangan merupakan perancanaan dan pelaksanaan atas : edukasi keuangan dan pengembangan infrastruktur yang mendukung litersi keuangan bagi konsumen.

Oleh karena itu, disamping hasil penelitian yang mendapati bahwa literasi keuangan masyarakat Indonesia itu rendah, maka pemerintah mengeambil peran dalam perbaikannya, yakni dengan cara melakukan serta memberikan edukasi keuangan dan pengembangan infrastruktur yang mendukung literasi keuangan bagi konsumen dan atau masyrakat. Materi yang di sampaikan mencakup beberapa informasi yaitu :

1. Pengelolaan Keuangan

2. Jenis Industru Jasa Keuangan

3. Produk Layanan jasa keuangan termsuk kareakteristiknya, yang teridiri dari :

a) Manfaat, biaya, dan resiko atas produk dan layanan jasa keuangan

b) Hak dan kewajiban konsuemn

c) Cara mengakses prosuk dan layanan jasa keuangan

d) Informasi terkait mekanisme transaksi dari produk atau layanan jasa keuangan tertentu

4. Perpajakan terkait produk dan atau layanan jada keuangan.

Adapun literasi keuangan syaraiah adalah kemampuan untuk memhami keuangan sesuai dengan syariat islam. Literasi keuagan Syariah juga harus sejalan dnegans prinsp Syariah islam, begitu pula pada saat mengenalkan keuangan kepada generasi setelah dan seterusnya.

\section{B. Konsep Literasi Keuangan}

Retzmann dan Seeber (2016) menganggap literasi keuangan sebagai sbeuah bagian dair konsep litersi ekonomi yang luas. Maka dengan begitu merkea mengidentidikasi tuga baidang kompetensi dalam literasi keuangan. Yakni: (1) pengambilan keputusan dan rasionalitas individu, (2) hubungan dan interaksi dengan orang lain, dan (3) tatanan dan sistem keseluruhan. Mereka menyebut ini bidang yang berakitan dengan hal literasi keuangan secara komprehensid dengan tujuan menciptakan manusia yang memiliki kometensi dan terididk secara finansial.

Sedangkan menurut Zokaityte (2017) ia memiliki keyakinan bahwa pemahaman yang kurang baik dalam literasi keuangan akan berdampak buruk pada kemampuan konsumen untuk memahami produk dan layananan keuangan yang di tawarkanpada mereka. Pemahaman akan inflasi, menejmen resiko dan disersifikasi protofolio pada investasi dangat berpengaruh dan penting dalam perkembangan ekonomi di masa depan.

Dapat di simpulkan bahwa keduanya menghendaki kompetendi dan terdiidkny amnsuia secara finanasial sebagai kemampuan kognitif manusia yang baik di tinjau secara tekns maupun keterampilan untuk menerapkan perancangaan itu. Dan, istilah terdidik finansial ini juga digunakan untuk mendeskripsikan seseorang yang mau dan mempu menilai, memutuskdan dan bertindak sexara mendidi dakan hal pengelolaan dan perencanaan keuangannya yang akan mencapati efek jangka pendek, janga menengah hingga jangka panjang pada orang yang bersangkutam.

Houston (2010) memberi pendapat bahwa literasi keuangan dan pengetahuan keuangan bagi setiap orang untuk mengelola keuangannya dengan benar, namun memiliki 
dimensi konstruksi yang berbeda. Dimensi pengetahuan finansial merupaan dimensi integral dari konsep keuangan secara menyeluruh, sedangkan literasi keuangan memiliki dimensi yang lebih menekankan pada unsur kemampuan dan keyakinan seseorang untuk menggunakan emampuan dan pengetahuan dinansialnya dalam membuat keputusan keuangan,

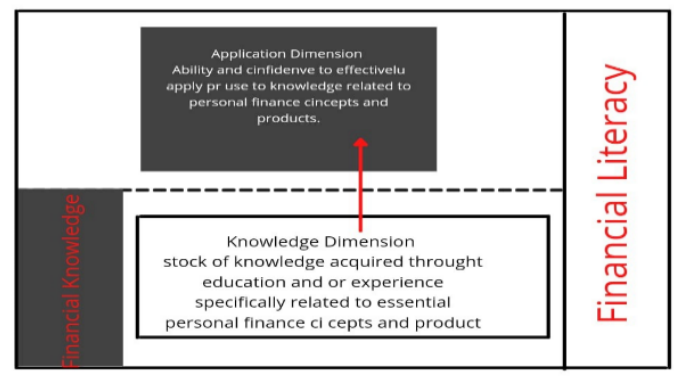

\section{Gambar 1. Financial literacy dan Financial knowledge}

Meski definisi dari literasi keuangan telah di ungkapkan namun tidak ada definisi yang bisa di terima secara universal. Namun berdsarakan gambar diatas, terlihat jelas bagaimana konsep literasi keuangan yang di sajikan dalam kerangka kerja konseptual. Literasi keuangan dapat di definsiikan sbeagai ukuran seberapa baik seorang individu dapat memahami dan menggunakan informasi terkait keuangan pribadi, definis ini langsung dan tidak bertentangan dengan definisi yang ada dalam liteatur dan konsistem dengan konstruksi keaksaraan standar yang lain.

\section{Faktor Yang Mempengaruhi Literasi Keuangan}

Studi mengenai factor apa saj ayang memiliki pengaruh langsung pada literasi keuangan telah banyak di lakukan oleh banyak peneliti sebelum ini, dan pada umumya ada empat factor utama yang menjadi acuan utamanya, yaitu usia, jenis kelamin, tingkat pendidikan dan pendapatan.

\section{1) Faktor Usia}

Para peneliti sepakat bahwa tingkat literasi keuangan yang di ukur berdarakan usa mendapati fakta bahwa gambaran tingkat literasi keuangan manusia mirip dengan punuk hewan mamalia. Yakni akan masih rendah untuk tingkat remaja, mulai meingkat dan peningkatannya pelin gtinggi berada pada usia dewasa, kemudian kembali merendah pada orang yang sudah memasuki usia lanjut.

\section{2) Faktor Jenis Kelamin}

Meski perempuan di kenal sebagaimakhluk yang tidak pernah salah dan benar, namun tidak berarti perempuan memiliki tingkat yang sama dengan lakilaki dala hal literasi keuangan. Banyak sekali kasus yang menyakinkan bahwa lakilaki memiliki literasi keuangan yang jauh lebih baik dari perempuan, dengan memberikan jawaban yang lebih yakin dan pasti mengenai piliahnnya mengenai urusan keuangan, ini berbeda dengan perempuanyang justru terjesan ragu dan tidak yakin mengenai hal yang dipilihnya mengenai financial.

3) Faktor Pendidikan

Penelitian yang di lakukan oleh Lusardi dan Mitchell pada 2017 dampai 2011 di Amerika Serikat mendapati hasil bahwa terhdapat perbedaan yang substansial dalam 
pengetahuan keuangan bila di lihat dari factor tingkay pendidikan. Hasil penelitian ini mendapati hasil bahwa orang orang yang tingkat pendidikanya rendah memiliki literasi keuangan yang rendah dan mereka yang mengenyam oendidiakn yang lebih tinggi memiliki literasi keuangan yang lebih cakap.

4) Faktor Pendapatan dan factor lainnya

Selain hal internal yang dapat berpenagruh pada literasi finansial seseorang, ternayat ada juga hal eksteraln yang merupakan bagiana tidak terelakkan, yakni pendapatan. Pendapatan memiliki pengaruh tak terelakkan karena jelas, tanpa adanya pendapatan maka akan sulit untuk menata dan megelola keuangan yang mayoritas hanya akan menambah pengeluaran.

Selain pendapatan, ada beberapa factor lan yang mejadi factor tinggi rendahnya literai keuangan seseorang. Seperti halnya etnis dan hal alinnya yang sebenanrya merupakan dampak dari kesenjangan osisal yang terjai disekitar mereka.

\section{Klasifikasi Tingkat Keuangan}

Menurut Otoritas Jasa Keuangan, tingkat literasi keuangan seseorang di bagi menjadi beberapa jenis tingkatan yaotu : well literate, sufficient literate, less literate dan note literate.

Tingkat Well Literate merupakan tingkatan di aman seseorang di angap memiliki pengetahuan dan keyakinan tentang Lembaga jasa keuangan serta produk jasakeuangan termasuk fitur, amnfaat dan resiko, hak serta kewajiabnnya. Kemudian ia juga memiliki keterampilan dalam menggunakan produk jasa keuangan.

Tingkatan Sufficeient literate merupakan tingkatan dimana seseorang memiliki pengetahuan dan keyakinan tentang Lembaga jasa keuangan serta produk dari jasa keuangan termasuk fitur dan mandaat juag resiko, hak dan kewajiban terhaitnya.

Tingkatan less literate merupakan tingkatan dimana seseorang hanya memiliki pengetahuan tentang lembag ajasa keuangan dan produk jasa keuangannya saja.

Sedangakn less literate merupakan tingkatan terendah dimana seseorang dianggap benar benar tidak memiliki pengetahaun dan keyakinana terhdap jasa keuangan serta produk dari jasa keuangan, bahkan ia tidak memiliki keterampilan dalam emnggunakan produk dan jasa tersebut.

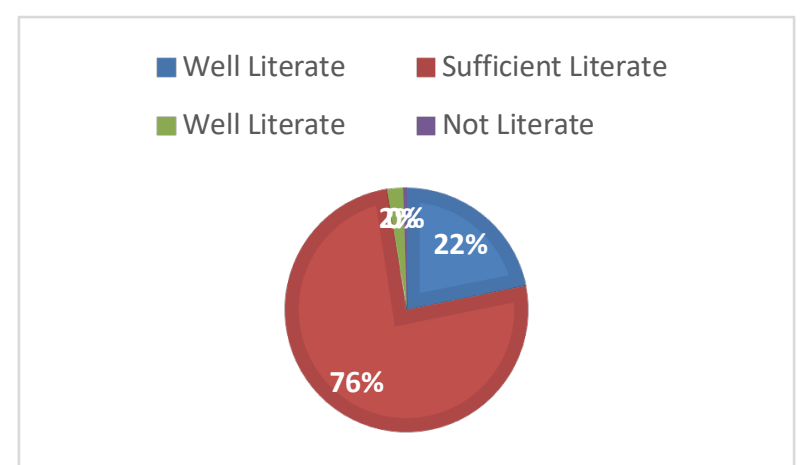

\section{Gambar 2. Tingkat Keuangan}

\section{E. Pentingnya Literasi Keuangan}

Literasi keuangan selalu di anggap penting bagi konsumen dalam membantu mereka menganggarkan dan mengelola pendapatan merkea, menabung dan berinvestasi secar aefisien kemudian mengindari dari keajahatan dan korban penipuan. Seirin gberkembangnya pasar keuangan yang semakin cangih dan rumah tanggayang kian membuthkan keputusan keputusan berisiko, maka literasi keuangan perlu dikaji lagi menajdi satu hal yang merupakan prioritas bagi setiap orang.

Pendidikan keuangab tidak semata memabahs tentang pengeluaran namun juag membuat perubahan yang baik dalam hal keuangan. Pendidikan keuangan merupakan 
proses dimana konsuemn keuangan meingkatkan paham dan pemahamnnya mengenai produk dan konseup keuangan melalyi infoermasi, instruksi dan saran yang pbyektif yang kemudian mengembangkannay amenjadi ekterampian dan keyakinan untuk menjadi lebih baik sadar akan risiko seta peluang keuangan untuk membuah pilihan berdasarkan indormasi untuk mengetahui kemana arah yang aan meingkatkan kesejahteraan finansialnya. Dengan pertimbangan dimana :

- Informasi menyediakan fakta, data dan pengetahuan yang spessifik untuk membuat mereka sadar akan peluang, piligan dan konsekuensi keuangan

- Instruksi memastian bahwa individu memperolej keterampilan dan kemampuan untuk memahami istilah dan konsoe kuangan melalaui penyediaan pelatiah dan pembimbingan

- Saran menyediakan konsumen dengan nasihat tentangkeuangan umum masalah dan produk sheingga mereka dapat memanfaatkan keuangan dengan sebaik baiknya informasi dan instruksi yang telah mereka terima.

Meski memiliki beberapa persamaan, anatar pendidikan literasi keuangan dan erlindungan konsumen, namun dipastikan bahw keduanya merupakan dua hal yang berbeda.

Perlindungan konseumen dan pendidikan literasi keuangan memiliki beberapa tujuan yang sama namum dengan metode pendekatan yang eberbda, dengan inti keduanya iaklah memastikan kesejagteraan konsumen dan melindungi mereka dari resiko keuangan. Penyedaiaan infrmasi tentang masalah keauangan biasa terjadi untuk du ahal ini, namun pendidikan keuangan melengkapi informasi dengan penyediaan instruksi dan nasihat sementari perlindungan konsumen dan menekankan perlindungan undang undangan dan peraturan yang di rancang untuk mengakkan standar minimum dan membutuhkan Lembaga keuangan untuk menyediaakan klien dengan informasi yang tepat. Dengan kata lain, perlindungan konsuemne menemptkan beban Lembaga keuagan dan sistem hukum sedangkan pendidikan literasi keuangan di bebankan keapda individu per individu.

\section{KESIMPULAN}

Dari penjelasan di atas dapat ditarik kesimpulan bahwa Indonesia merupakan Negara dengan masyoritas penduduknya beragaama Islam dan negaranya melegalkan hukum Syariah yang berdiri didalamnya, oleh sebab itu perbankan di Indonesia juga ada yang berbasiskan Syariah atau berdiri atas hukum Islam.

Secara umum, literasi keuangan di Indonesia tergolong rendah dan hal itu di buktikan oleh banyak penelitian mengenai itu yang diselenggarakan oleh Otoritas Jasa Keuangan. Mengetahui hal itu, pemeirntah Indonesia dengan sigap membeirkan tanggapan akan hal itu dan memberikan sumbangsihnya dengan memberikan keluasan dan kesmepatan keapda penyediaa jasa keuangan berbentuk Lembaga untuk dapat memberikan pemahmannya keapda msayrakat melalui infrastruktur dan fasilitas lainnya.

\section{SARAN}

Sebagai penyusun jurnal ini, penulis menyarankan untuk seluruh orang yang membaca jurnal ini untuk menanamkan niat hati mengembangkan literasi keuangannya baik secara global maupun Syariah, hal ini merupakan hal yang cukup penting untuk mendapatkan kesejahteraan financial di masa yang akan datang dan mungkin saja bisa membantu dalam mewujudkan financial freedom dambaan bersama.

Pemerintah sudah cukup memberikan andil yang layak dalam hal pemberian, penyaluran informasi dan penegakan kepentingan kepentingan literasi keuangan untuk masyrakat, namun kini masyrakat perlu mengetahui hal hal dan sampak buruk mengenai 
tidak mengindahkannya hal tersebut dan memberikan gambaran mengenai apa apa saja yang tidak mereka dapatkan.

Pihak perbankan atau Lembaga jasa keuangan lainnya hendaknya memberikan gambaran yang lebih melalui promosi degan sasaran pemasaran yang tepat, karena dengan begitu saya rasa cukup meningkatkan pemahaman literasi keuangan masyrakat Indonesia.

\section{DAFTAR PUSTAKA}

Ahyar, M. K. (2017). Literasi Keuangan Syariah Dalam Konteks Pondok Modern (Studi Kasus Pondok Modern Asy-Syifa Balikpapan). Surakarta: Institut Agama Islam Negeri Surakarta.

Atkinson, A. and Messy, F-A. (2012), -Measuring Financial Literacy: Results of the OECD INFE Pilot Studyll, OECD Working Papers on Finance, Insurance and Private Pensions, No. 15, OECD Publishing

Badan Pengembangan dan Pembinaan Bahasa Kementrian Pendidikan Indonesia. (2016). Kamus Besar Bahasa Indonesia. Retrieved from kbbi.kemendikbud.go.id: https://kbbi.kemdikbud.go.id/entri/literasi

Carmela Aprea et all, International Hand book of Financial Literacy, Siangapore : Springer 2016

Dewan Komisioner Otoritas Jasa Keuangan. (2016). Peraturan Otoritas Jasa Keuangan Nomor 76/POJK.07/2016 Tentang Peningkatan Literasi dan Inklusi Keuangan di Sektor Jasa Keuangan Bagi Konsumen dan/atau Masyarakat. Jakarta: Menteri Hukum dan Hak Asasi Manusia Republik Indonesia.

Jay Liebowitz, Financial Literacy Education, CRC Press : New york 2016

Kempson, E. (2009), - Framework for the Development of Financial Literacy Baseline Surveys: A First International Comparative Analysisll, OECD

Marlina, potensi pesantren dalam pengembangan ekonomi syariah jurnal hukum islam (jhi) volume 12 , nomor 1 , juni 2014

Mohamad Azni Abdullah, S. N. (2017). Factors determining Islamic Financial Literacy among Undergraduates. Journal of emerging economies and islamic research, 67-76.

Remund, David L. 2010. Financial Literacy Explicated: The Case for a Clearer Definition in an Increasingly Complex Economy. The Journal of ConsumerAffairs Vol.44 No.2.

Sandra J Houston, 2010, Measuring Financial Literacy, The Journal of Consumers Affairs Vol. 44 No 22010.

Ulfatun, Titik, dkk. 2016. Analisis Tingkat Literasi Keuangan Mahasiswa Fakultas Ekonomi Universitas Negeri Yogyakarta Tahun Angkatan 2012-2014. Jurnal Pelita Vol.XI No.2.

Widayati, Irin. 2012. Faktor-Faktor yang Mempengaruhi Literasi Finansial Mahasiswa Fakultas Ekonomi dan Bisnis Universitas Brawijaya. Jurnal

Working Papers on Finance, Insurance and Private Pensions, No. 1, OECD Publishing. doi: $10.1787 / 5 \mathrm{kmddpz} 7 \mathrm{~m} 9 \mathrm{zq}$-en 